\title{
Selected Shariah Issues in Sukuk Structures: A Comparative Approach
}

\author{
Mohamed Benaicha
}

Bandar Mohammed Saif Qasem

Anas Abdulkadir Abubakar Kassim

\section{International Islamic University Malaysia (IIUM)}

\begin{abstract}
The purpose of this paper is to explore the extent of Shariah compliance in the contracts underlying sukuk structures and their conformity to the objectives behind such contracts. It does this by exposing the prevalent opinions to a maqasid matrix to judge their validity. The Shariah issues underlying sukuk structures are divided into four primary issues that pertain to a certain category of sukuk or most sukuk regardless of the category and focus on the most important and prevalent issues as identified by Islamic economists, jurists and other researchers. The most important findings are that the issues as they relate to important principles and elements of muamalat or Islamic contracts law exist and are real including, but not limited to: possession and legal or beneficial ownership of assets, the debt nature of sale-based sukuk, lack of PLS considerations, and the loss of contact with the real economy. The literalists approach does not incorporate Shariah objectives as ideal standards for sukuk structuring, and similarly, the alternative approach features reductionist tendencies to certain principles. This research provides a theoretical basis on which to judge, from an objective perspective, sukuk issuances and so does not provide practical steps to implementation. This paper takes a much-needed comprehensive look at sukuk structuring in light of the means and objectives of the structuring practice and is expected to provide an original dynamic alternative for scrutinizing structuring practice.
\end{abstract}

Key words: Islamic securitization; sukuk; Shariah issues; maqasid 


\section{Introduction}

With the relatively rapid growth of the sukuk industry, the line between Shariah compliant and non-Shariah compliant can become blurred, especially with the existence of profit incentives and the demand for safety, security and guarantees of investor capital. Shariah advisors or committees are often forced to compromise on the objectives of muamalat for the sake of a more 'realistic' approach to raising the share of Islamic assets in the market. The idealists however, such as Islamic economists, don't seem to be content with this as they see that principles such as means and ends, maqasid or objectives, profit/loss sharing (PLS), possession and ownership are not to be compromised in the attempt to advance Islamic financial asset share, regardless of the circumstances. A middle path is taken by other Shariah experts who take an objective-based approach to appraising current products and practice in light of Shariah law; this does not adopt a reductionist approach as do both realists and idealists but rather a holistic study of the spirit of the law enabling a more objective appraisal of such products and practices. This latter approach is expected to create the common ground necessary for both idealists and realists to come to terms with each other.

The diversity of sukuk issuances has allowed for new classifications based on their commercial functions and based on the investors' relationship with the asset which differs based on who they have recourse to - all of this considering that all sukuk claim to give investors direct ownership of the assets or shares in the projects. Current practice raises several questions regarding the debt nature of sale-based sukuk, the ownership issues as they relate to legal or just beneficial ownership, PLS issues as they relate to the purchase undertaking (PU) and fixed redemption prices, and the accumulation of all of these issues to the loss of contact with the real economy of the sukuk that claims to achieve the hallmark elements of Islamic muamalat of ownership, value added and productive assets.

To understand the debate regarding the Shariah issues prevalent in sukuk structuring, it is important to understand the overall approach adopted by the scholars and researchers in the field. While it is hard to pinpoint every detail, the general elements of the approach can be summarized as follows:

A group of experts view that the apparent form of contractual structures is given precedence rather than the substance. This has significant implications in judging the contracts that make up the sukuk. This group generally invokes the reality of the Islamic finance industry and its small market share as a justification giving rise to the necessity of relaxing some constraints imposed by the comprehensive muamalat law. Nevertheless, such a justification is also in accordance with the spirit of the law, namely, that necessity and constraint facilitate ease and flexibility, and is considered by the vast majority of experts to be a concessionary condition for adopting a more realistic approach to Islamic finance rather than an idealistic approach.

The idealistic approach is adopted by others who emphasize and perhaps over-idealize the necessity of some principles, such as an equity-based approach to sukuk structuring in which profit and risk of loss are shared and in which any sort of debt is absolutely prohibited. While such a group believe that these principles of PLS and the elimination

International Journal of Management and Applied Research, 2019, Vol. 6, No. 4 
of debt from commerce is necessary for just distribution and wealth preservation, they seem to overlook other important objectives of the prohibition of certain (interestbased) debt and implications of the Prophetic narrations that make mention of PLS.

Finally, there is another school which advocates for a reinterpretation of the Shariah texts, which requires not only a solid grounding in Shariah studies and Arabic, but also a comprehensive understanding of the pre-existing juristic literature. This approach believes that the reinterpretation of the texts will result in construing a variety of Shariah objectives from the infallible Divine texts themselves. In light of this and technical knowledge of the respective practice or economic/financial discipline, a scholar has the necessary tools to pass judgment as to the Shariah compliance of products and practices. Hence according to them, sukuk feature a variety of Shariah objectives which need to be weighed against each other and whose elements need to be looked at from the perspective of the spirit of the law.

The research is limited to selected issues and to library-style research which will refer to previous literature as well as current industry material to analyze the reality of sukuk structuring, issuance and redemption practices. This paper is also limited to issues inferred by academicians and researchers on the classical scholars and does not refer directly to fiqh (legal) compendiums and expositions; reference to the Shariah texts is not a limitation of this research.

\section{Literature Review}

The securitization phenomenon in Islamic finance has the same underlying issues that banking products do because of their common basis, namely, Shariah contracts. The contracts themselves are a reflection of an exchange in the real sector and so too the sukuk which are based on these contracts (Rizvi et al., 2016). That is not the case in practice however as El-Gamal (2006) famously argues but, instead, the underlying contracts at times do not reflect real sector elements such as supply/demand and market price movements or the contracts themselves are not real in that they are combined to replicate a conventional bond (Rohmatunnisa, 2008). Just like conventional bond issues, AAOIFI for example has allowed the redemption of ijarah sukuk assets at other than their market value, namely, their nominal or face value (Lahsasna and Idris, 2008), while the likes of the IIFA (International Islamic Fiqh Academy, OIC, Jeddah) have recommended it be on a non-binding voluntary commitment (Wilson, 2004).

Debt practices also dominate sukuk structuring, from arranging debt-based financing (Krichene, 2013) to moving corporate debt off the balance sheet through certain forms of securitization (El-Gamal, 2006), with some differentiating between the benefits of Shariah approval of debts for productive finance and those for consumption (alRaysuni, 2013). There is however a subtle feature that differentiates debt that results from productive activity such as a sale and that which is initiated for commercial purposes; a mark-up on the former is acceptable as it is real sector determination of price, whereas in the latter, it is akin to riba - interest (Laldin and Furqani, 2013). Furthermore, sale-based debt financing is the Islamic alternative to interest-based debt financing (Kahf and Khan, 1992).

International Journal of Management and Applied Research, 2019, Vol. 6, No. 4 
A similar case is made in the case of financing through securities issuance such as sukuk. Early Islamic economists visualized a debt-free economy according to Kahf and Khan (1992) meaning that any sort of financing through sukuk would have had to have been through partnerships and based on PLS (musharakah) or just profit-sharing (PS mudarabah). Later critiques would emerge to challenge the PLS principle in Islamic banking operations; the same can be said for sukuk structures which are a reflection of such practices (Kahf and Khan, 1992).

Furthermore, asset ownership should be a full legal ownership, supported by a transfer of assets; risk and returns should be linked to the performance of such assets (Wilson, 2008; Lahsasna and Idris, 2008). This would be in furtherance of realizing the PLS ideal in the cases that assets are lost or destroyed the owners would bear the losses and not the issuer. The reality is that this is only partially fulfilled in that the transfer of assets is only temporary, and that ownership is only beneficial (Ghani, 2017; Safari er al., 2014); or it may be that the originator even intends to keep the asset, legally, and not confer real ownership (Wilson, 2008).

The idealized ijrarah sukuk for example exhibits these characteristics and determining fair market value is hard as the market for these assets does not exist. With the exercise of the option to sell (redeem) the asset by the issuers (to the issuer), ijarah sukuk can be devised for any useful asset (Ali, 2005). Finally, and related to the legal ownership issue, Dusuki and Mokhtar (2010) affirm that the investors' interest in the underlying asset is merely as creditors instead of as owners; in partnership sukuk structures, no legal due diligence is rendered by the issuer (legal/accounting transfer) in the structuring meaning no consideration is given to the real ownership transfer.

\section{Methodology}

The methodology uses a critical qualitative method of analysis of current sukuk structures in attempting to dissect them and separate the underlying contracts and analyze them in light of Shariah objectives and as they relate to the overall bundled security. The data will be gathered mainly through library research from previous literature on sukuk structure and their underlying contracts; the researchers also refer directly to the Shariah texts for an inductive reading. The analysis will look at the primary components of the structuring process and discuss the relevant criticisms of contentious practices, as well as shed a maqasid light on the issues.

\section{Findings and Discussion}

Issues underlying sukuk structures

After a thorough review of a number of common sukuk structures, the researchers have identified several serious issues including their debt nature, ownership issues, PLS consideration issues and loss of contact with the real economy. Several different sukuk structures will be discussed which embody such issues including murabahah sukuk, istisna' and salam sukuk, ijarah sukuk, hybrid sukuk, and mudharabah and musharakah sukuk structures. Furthermore, brief allusions to certain issuances will be made and the relevant issues pinpointed. There will be an attempt to make a fair evaluation of the justifications of such practices and the arguments for and against such structures. Brief allusions will also be made as to the level of conformity of such

International Journal of Management and Applied Research, 2019, Vol. 6, No. 4 
practices - including the arguments presented - to maqasid, or "the spirit of Shariah law'.

The debt nature of sukuk structures

Although most Islamic finance textbooks and writers claim that sukuk differ from conventional bonds in that the former are asset-based or asset-backed - representing ownership - while the latter are debts that represent a claim to capital, industry practice is far from this ideal (Dusuki, 2016; Safari et al., 2014). In practice, they are classified under finite-period debt and are rarely equity securities with fractional ownership of the asset and a share in profit and risk (Safari et al., 2014). The justification for this was that funding for economic activities was necessary and hence the most Shariah compliant products need to be devised to meet this necessity - although alternative equity-based structures do exist. Such sukuk are initially equity-based arrangements in which the SPV receives all contributions which are owned by the investors. But very quickly this equity-based relationship turns into that of debt. The murabahah, salam and istisna' sukuk have all been deemed as debt securities because of the nature of the underlying contracts:

1. In the murabahah model for example, the capital is used to buy commodities and sell it at murabahah cost-plus to the issuer of the sukuk, which become a debt upon the issuer just as a conventional bond; the issuer then sells the commodities for cash. In applying fiqh al-ma'aal (consideration for the ends and consequences), these sukuk ultimately represent a debt instrument that resembles a conventional debt security, not to mention that installment payments (coupons) maybe tied to some benchmark rate (Wilson, 2008). AAOIFI has as a result banned their secondary market trading (Lahsasna and Idris, 2008; El-Gamal, 2006).

2. The case of salam sukuk (Dusuki, 2016) is similar since they represent a debt for the sukuk holders in that the muslam fih (commodity to be delivered) is an entitlement of the sukuk holders which would later be sold at sukuk maturity for them to redeem their shares. Salam contracts were traditionally permitted for purposes of dire necessity for which the farmer had no alternative for crop production except through initial funding to cultivate the land. This concession has been expanded beyond these parameters and used as a basis for a debt instrument for things such as monetary policy.

3. The isitisna' sukuk also represent debt certificates in which the manufactured product-to-be is the debt obligation to which sukuk holders are entitled. Istisna' is much less contentious as a structure since project developers need initial funding to construct building/equipment and so - just as in the classical juristic period - the istisna' debt payment is accepted only due to such a need.

The implications of this issue is that objectives of Shariah, which aim to establish property ownership rather than property claims (insha' al-milkiyyah; al-asl adam tashghil al-zhimam, respectively), are not being met properly; such certificates do not embody the objective of gratuitous loan (qardh hasan) well either, since it should be kept strictly outside of commercial undertaking (Laldin and Furqani, 2013), but rather they convert loans into commercial for-profit vehicles. Furthermore, due to the pure debt nature of such instruments, scholars have almost unanimously barred their trading

International Journal of Management and Applied Research, 2019, Vol. 6, No. 4 
rendering a secondary market absent for such instruments which further discourages their use (resolution/ruling \#178, 19th session, 30 April 2009, UAE).

Such arguments are put forward by critics of the practice, while its advocates argue that the initial sale did take place which is a transfer of ownership as will become clear. Furthermore, they apply the legal maxim that the structure of contracts takes precedence over their substance, and in this case, they are permitted sales which renders them permissible. Either way, the arguments for both sides, as discussed, feature reductionist tendencies in that their stance is founded on two or three pieces of evidence which have not been subjected to scrutiny through the Shariah texts and their complex and dynamic web of objectives.

The murabah sukuk issuance of Arcapita Bank utilized a traditional commodity murabahah structure which it used to get cash funding while paying a floating LIBOR $+175 \mathrm{BPS}$ for a period of 5 years. The murabahah commodity is held by the SPV until maturity of the debt and was sold by the SPV to the originator for the proceeds to repay the principal on a bullet payment basis. Although the contracts apparently comply with the juristic expositions of sale contracts, a dynamic Shariah objectives framework would perhaps allow such setups in financing productive assets/ventures (al-Raysuni, 2013; Choudhury, 2015), but would prohibit them as purely debt-based liquidity tools used to finance further speculative capital due to the inflationary effect that would have on prices and currency.

Similarly, Krichene (2013) argues that since the purchase of assets nevertheless exists in sukuk, be they debts in nature such as sale-based sukuk or others, the direct link to real sector activities curbs speculative movements and hence, financial crises. The productive nature of sukuk, be they debt-based or not, has to be weighed against the negative implications of debt-based funding of productive ventures to determine their acceptance according to the spirit of the Shariah law as no explicit injunctions either prohibiting or encouraging debt-based financing of a productive venture exist.

The Tabreed istisna'-ijarah sukuk are also debt obligations upon the issuer (in this case the NCCC, UAE). Before the completion of construction of the underlying asset, they are simply loans made by investors to the issuing company. Considering that such rights are fungible in nature, this renders the actual sukuk themselves as debt-based sukuk before the completion of the project. Hence, the Tabreed sukuk are initially istisna' contracts which represent debt obligations, and hence cannot be traded, and then become ijarah sukuk in which issues such as beneficial ownership come into play - besides the purchase undertaking (PU) and the consideration for PLS. The fact that they are used to finance a productive asset renders them productive financing which is not problematic from the maqasid perspective towards debt-based sale financing as previously shown.

The hybrid sukuk model as an alternative to pure debt sukuk

These sukuk were introduced to enhance the mobilization of funds to allow for Shariah compatible finance. Although scholars have differed on the permissibility of such sukuk and their tradability, the IIFA (resolution/ruling \#178, $19^{\text {th }}$ session, 30 April 2009, UAE; the actual resolution pertains to general securities whose underlying assets are mixed cash, assets and debts) has permitted it on the basis that the majority of underlying assets are indeed assets and not debts.

International Journal of Management and Applied Research, 2019, Vol. 6, No. 4 
The contention is mainly surrounding the mudda ajwah Prophetic narration in which a number of prominent jurists have permitted trading a ribawi (usurious) commodity for another which is a non-ribawi commodity that has been mixed or combined with a ribawi element (such as gold for a gold-decorated plate or sword as an example given by the jurists). The same logic has been applied to hybrid sukuk in which assets have been mixed with debts and which are bought and sold using money, hence the concession granted by a number of prominent scholars such as Ibn Taymiyyah and a vast number of Hanafites has been used to justify these sukuk when studying the ultimate implication of such a practice. This has opened the door for profit-oriented 'Islamic' entities to trade in sukuk that are comprised of only $10 \%$ assets. This may be a result of the 'paradoxical nature of the majority rule', as El-Gamal (2006) put it, in which the asset portion of the hybrid bond is stripped away and bought back at market price and is then bundled with other debt, ensuring the 51:49 ratio of tangible assetsto-receivables is maintained. Hence, the initial goal of allowing the mobilization of capital has simply led to the inclination to deal in purely debt-based securities.

The opponents of such practices hold that the substance of such contracts is that they are securitized debt and that trading debt is impermissible due to the existence of riba, in that cash - dollars let's say - in the form of securities is traded for other cash at differing values which constitutes a usurious transaction. However, it is less applicable here in the case of hybrid sukuk, since first, the purpose is to facilitate tradability of real asset/project shares, and second, a prohibition would hinder the objective of liquidity of capital which the scholars have identified as an important objective and to which a number of Shariah texts attest (El-Mesawi and Ahmed, 2016).

This has forced a lot of sukuk issuers to resort to issuing the next type of sukuk in this discussion, sukuk al-ijaraha. The Islamic development bank (IDB) issued the first hybrid sukuk which are composed of $65.8 \%$ sukuk ijarah, $30.73 \%$ murabahah and $3.4 \%$ istisna', the latter two being debt in nature and hence may comprise only $34.13 \%$ of underlying assets. Furthermore, the sukuk were guaranteed in the same way as conventional bonds to give them international acceptance. It comes as no surprise that some scholars were critical of the issue of such sukuk and the guarantee added on top, nor is it surprising that advocates of strict legal ownership are equally as critical of such an issue.

Ownership issues in ijarah sukuk

Ghani (2017) defines ownership in Islamic law as possessing four fundamental elements:

1. Legal and exclusive ownership between individual and asset

2. Intention of exclusivity which gives the right to either use or dispose of assets owned

3. The ability to use or dispose of the asset owned without impediments

4. This ability may be $i b t i d a ' i$ or taba' $i$ (without reason or through contractual obligation respectively).

The problem with the currently prevalent ijarah model for sukuk structuring is that, while sukuk structures claim to give legal ownership of the underlying asset, the actual practice entails transferring only beneficial ownership for purposes of issuing the sukuk

International Journal of Management and Applied Research, 2019, Vol. 6, No. 4 
and not complete ownership. This goes against the implications of ownership of the initial sale contract (Ghani, 2017), and has in fact been judged in substance to entail no interest in the lease asset for the sukuk holder (Dusuki and Mokhtar, 2010). Kamali (2007) however, argues that the point is that ijarah sukuk ultimately represent undivided ownership in the leased asset which renders them like equities, perhaps because the ijarah assets are bankruptcy remote.

Another issue is the repurchase undertaking, specifically, the initial sale and the stipulation of a repurchase (at redemption); such a stipulation is contrary to the exclusiveness of sale maxim which states that two simultaneous contracts such as a sale and purchase shall not apply to one the same object (which is binding and is hence indicative of a sale) - tawarud 'aqdayn fi ainin wahidah. The lease and purchase arrangement (ijarah muntahiyyah bi tamlik) has only been permitted by the IIFA (resolution/ruling \#110, 12 ${ }^{\text {th }}$ session, 23-28 September 2000, Riyadh) on the grounds that it is a rental accompanied by a purchase undertaking or PU, not a sale and a simultaneous repurchase undertaking following a rental of the asset (both in the form of a master lease and reoccurring subleases) as is the actual practice. Safari et al. (2014) criticize this as being akin to conventional bond practice. Kamali (2007) further allude to this as being one of the main pitfalls of sukuk according to Shariah scholars.

The arguments against this are that first, the PU as a promise which is binding, is permitted by some jurists. Second, the apparent forms of the contracts are valid which renders them Shariah compliant; a binding promise is merely a promise and not a second contract applying to the same object, and that the initial sale entails transfer of ownership, even if the issuer has no interest in giving up its ownership interest in the asset. In aligning this view with Shariah objectives, the advocates of this view claim that the necessity for such structures to meet investor need for security of principal dictate that a PU be stipulated at the face value of the asset.

The arguments, both for legal ownership and against, it are still largely reductionist in nature; they fail to incorporate the other objectives such as the objective to preserve wealth, to circulate wealth, to spur productivity by funding assets through sukuk securities, and the interest of limiting any sukuk holder from freely trading in the asset since the generality of sukuk holders have interest in the asset (in times where sukuk holder rights may be compromised, such as delinquency events, the sukuk holders are given the right to sell the asset for cash).

Furthermore, such objectives of muamalat law need to be ordered so as to determine their priority in the case that not all such objectives can be achieved. While the PU contradicts the risk principle (PLS), PLS itself is constrained by the objective of preservation of investor capital and wealth that is highly regarded in Shariah. The implications of freedom, such as the freedom for private ownership, are furthermore constrained by the extent of the uncertainty and resulting disputes that would occur due to lack of proper legal possession. Furthermore, the apparent structure of the contract (of purchase and consecutive repurchase) disregards most of the objectives and considerations discussed. Finally, the arguments of both sides limit their evidence to the principles or maxims, such as justice in PLS and utility realized in investor security, which either fail observe the historical context in which such principles and maxims were devised or overemphasize them relative to other principles and

International Journal of Management and Applied Research, 2019, Vol. 6, No. 4 
objectives in the hierarchy of Shariah objectives as will become clear at the end of the discussion.

One of the most prominent issues of ijarah sukuk was that of Kumpulan Guthrie Berhad valued at US\$450 million based on the lease and purchase contract. This was a pure financing scheme for the acquisition of palm oil plantations in Indonesia. The additional put and call options can only be exercised at scheduled or unscheduled dissolution events such as delinquency or maturity which raises questions as to the legitimacy of legal ownership of the underlying assets; this is claimed to reduce gharar (uncertainty) as will follow when discussing the PU. Furthermore, the contracts involved which are lease and sale, are completely valid according to the literalists' view, opting for judging apparent form rather than substance of contracts; they also feature a binding promise or repurchase of the plantations from the SPV by the originator which has been permitted by some jurists.

Purchase undertaking, PLS issues and loss of contact with the real economy

The next major issue that is discussed is the PU which is rampantly practiced in sukuk issuance. Although Safari et al. (2014) admit that in order to avoid dealing with riba (interest), sukuk securities should be based on something with real economic value, such as equities or physical assets, the fact is that most returns on sukuk have no relation to the underlying asset performance or their economic value. According to Lahsasna and Idris (2008), AAOIFI has allowed that the assets redeemed by the originator redeemed at nominal value, which raises questions in respect of conforming to the Prophet's (Muhammad PBUH) command that profits (from the returns in the case of sukuk) are earned by bearing the risk of loss. It is necessary to revise the Prophetic command in light of Shariah objectives and to determine whether such a command is itself all-encompassing, or whether it was intended merely as a means to an end, that is, for realizing fair distribution of profits and risks in financial dealings. In sale-based sukuk, the market risk is mitigated when it comes to redemption. The counter arguments are that the binding promise has been permitted by some scholars, but this according to El-Gamal (2006), is on the basis of a solitary opinion attributed to a Maliki jurist (Ibn Shubrumah); the other argument is the original and general permissibility to contract in various forms by the Shariah (al-ask fi al-mu'amala alibahah). Hassan and Lewis (2007) in response to such a practice in ijarah sukuk go as far as to argue:

"In the Bahrain, Malaysia and Qatar deals, there was a commitment from the government to buy back the leased assets at a price sufficient to meet the sukuk obligations. These guarantees by the borrowers are so central to the credit enhancement of the sukuk that the credit rating agencies do not look very closely at the assets in the underlying pool. This may be contrasted to what would be expected in a conventional asset-backed deal, which suggests that sukuk are more similar to covered bonds than to securitizations" (Hassan and Lewis, 2007: p. 58)

Tariq and Dar (2007) argue that the viewpoint of jurists is that musharakah arrangements would strengthen the paradigm of Islamic banking that considers partnership contracts as the embodiment of certain core ideals. The manager (originator) undertakes buying the assets underlying the mudharabah/ musharakah

International Journal of Management and Applied Research, 2019, Vol. 6, No. 4 
sukuk from the holders at a pre-arranged price, regardless of the actual market value (Krichene, 2013). The rebuttals of this argument are weak and not properly articulated:

- The first argument is that the mutual consent for the purchase undertaking is present for an agreed-upon exercise price by the investors and issuer which would reduce any disputes in the future as to the exercise price (or redemption price) of the sukuk. The 'mutual consent validates all contracts' argument is often presented as justification but fails to observe the spirit of this which is to achieve fairness in transactional dealings. Exposure to market price fluctuations (embodied in PLS) would then be a constraining factor which would require that such assets relate directly to real prices and the real economy and work towards achieving a sense of justice in ensuring real earnings and losses are accurately reflected.

- Another argument is that such sukuk arrangements are not devoid of all risks since operational risks and performance risks are still present. However, fairness is compromised when the investors have their capital guaranteed, since the business venture may not necessarily succeed in which case the originator would bear all the losses.

- Industry practice ('urf) entails that sukuk are deemed to be fixed-income certificates with the guarantee of principal and profit being essential for creditrating considerations (Krichene, 2013). Such a convention blatantly contravenes the concept of assets and business that are tied to the real sector and that is indicative of real prices which is why such conventions are not regarded as valid by the Shariah.

Beside the purchase undertaking, forgoing (tanazul) of one's rights to profits where a profit equalization reserve (PER) is established in which some profits are withheld from investors if the actual returns are higher than expected to cushion future losses is also a mechanism developed to maintain fixed periodical return payouts (the opposite is also practiced where the issuer forgo his profits in the case that market performance is under the benchmark or expected rate). A number contemporary jurists along with ardent advocates of PLS both deem it as a legal stratagem to circumvent the PLS principle in Islamic finance; AAOIFI's chairman Taqi Usmani was against such a practice if the commitment to fill any shortfalls in expected returns by a credit facility, although the PER facility was approved by AAOIFI and strongly recommended by Lahsasna and Idris (2008) since it does not contradict Shariah profit ideals or objectives. Although tanazul has been discussed by classical jurists and accepted in some musharakah undertakings, it was only ex-post without it being binding, that is, after profits have been calculated and were ready to be distributed; in today's practice, it is pre-arranged, pre-approved and binding in nature (Magalhães and Al-Saad, 2013).

However, other scholars have argued that such a provision and provision of credit (liquidity) facilities are to ease out fluctuations between underlying asset performance (returns) and returns to investors in an attempt to meet the needs of more risk-averse investors (Tariq and Dar, 2007). The debate over PLS and market risk has persisted for a long time and has predictably spilled over to the securitization process and financial engineering of instruments such as sukuk. In anticipation of this, some prominent Islamic economists and financiers such as Chapra, Kahf and Khan have adopted a middle path in their approach to this debate, namely, to establish the Shariah

International Journal of Management and Applied Research, 2019, Vol. 6, No. 4 
permissibility of both contract modes of financing (PLS and mark-up) and then to concentrate on the suitability of one or the other to a particular economic environment (Khan, 1995). Ultimately, the objective of Shariah are diverse and dynamic aiming to achieve justice as well as security, liquidity and transparency, which all need to be factored in when determining the viability of industry practice.

In the Lagoon City musharakah sukuk issue (musharakah mutanaqisah sukuk), the 2year sukuk promised a purchase of the asset from the investors at a predetermined amount, regardless of prevalent rental market prices. It is the last point regarding the undertaking by the originator to buy the shares of the SPV in the musharakah at face value at a pre-agreed price and not at market price which has caused disagreement among contemporary Shariah scholars (Al-Amine, 2008). The same can be said for the DP World Sukuk which are mudharabah sukuk in which DP World must promise (binding) it would purchase the issuer's interest in the mudharabah venture at maturity which was priced at outstanding principal plus accrued unpaid return (Dusuki, 2016).

Furthermore, Hassan and Lewis (2007) point to some subtle implication of the debtbased approach which requires the firm to meet fixed obligations, instead of adopting a PLS approach, and the relation of this with the real sector. That is, demand shocks cause over-reaction on behalf of creditors in debt-based financing and freeze up credit due to defaults and lending scare, but not so in PLS system where creditors expect demand shocks to reduce returns since such financing methods - or investments - are tied to real sector performance. Debatably, the same can be said for the firm's financing when meeting mandatory sukuk payouts since a single default may very negatively hurt its rating and hamper its future borrowing ability.

All such issues contribute to the loss of contact with the real economy. It is obvious that such practices are by no means ideal but, at the same time, ideals are hard to attain; Choudhury (2015) notes that, attachment to the real sector means that the financing or proceeds be directed at the actual asset that is used for production or adding value. Through inference, such a claim applies both to direct finance or indirect finance through securities such as sukuk. The objective-based approach maintains Shariah relevance while attempting to provide realistic solutions for any economic circumstances. For this reason, the ideal method of asset financing, if sought after to the detriment of other important objectives, must be weighed against these other objectives to determine its feasibility.

A distinction is made between sale-based and partnership-based sukuk in which the former are based on sale contracts which can have their deferred price fixed with a mark-up and so the undertaking to purchase the assets at face value is not problematic at it relates to market risk; the latter case of partnerships is where the problem lies since scholars have unanimously banned the redemption of partnership shares based on nominal valuation since it is tantamount to guaranteeing the initial investor capital (AAOIFI as in Lahsasna and Idris (2008), and IIFA in resolution \#188, $20^{\text {th }}$ session, 13-18 September 2012, Oran). The reality is that in practice, the sale-based sukuk of murabahah and salam are used purely for financing with the underlying assets only being relevant so as to fulfill the condition of presence of commodities or assets in the contract.

International Journal of Management and Applied Research, 2019, Vol. 6, No. 4 
Figure 1.0 illustrates a maqasid (objectives) matrix and their primacy in the Shariah system of law as viewed by the researcher:

- The debt-based nature of a lot of sale-based sukuk and the criticisms directed at such practice in sukuk structuring pertain to objectives (a).

- Ownership issues pertaining to objectives indicated by (b).

- PLS considerations pertaining to objectives (c).

- Real sector/real economy contact pertaining to objectives (d).

- All sukuk structures undoubtedly allow for greater investment opportunities and hence circulating capital, facilitating capital markets, and are ultimately based on one or more contracts; Shariah objectives that pertain to that are indicated by point (e).

Each aspect is elaborated below:

(a) Debt-based transactions are either market-related or non-market loans. The latter include qard hasan whose objective is benevolence and mutual aid. The former may include interest-based lending or sale-based debt financing. When debts do not relate to real assets or value-adding projects, they hinder the realization of Shariah objectives in the Islamic economic system since they become for-profit vehicles - money that is commoditized. Furthermore, as debts that are not related to assets, they are abstract assets in nature, they raise questions as to their legal nature since Shariah idealizes private ownership which is tied to actual assets and not simply claims to assets (receivables). It has already been stated that in practice in the likes of murabahah and salam debt sukuk, there is complete neglect for such considerations with the underlying commodities being used to satisfy the Shariah requirement to validate contractual form but not to realize production objectives of such contracts.

(b) Building on the previous point, transparency is also another Shariah ideal of Islamic economics which is subtly compromised by the nature of the assets that are used to structure certain sukuk when no intention of delivery or transfer of ownership is present. Transparency is essential for minimizing gharar whose dire importance will be felt when issues start arising in the sukuk industry and when delinquencies proliferate.

(c) As discussed, PLS considerations are absent in important aspects of sukuk structuring, especially in partnership-based sukuk, which hinders justice and fairness for the issuer since regardless of the prevailing market realities, the redemption of shares is done at the book value of the sukuk. Hanif (2016) argued that the redemption price of Sukuk should be based on the actual market value of assets, instead of redeeming at par value.

(d) Ultimately, the real sector for goods and services is what determines prices through mechanisms of supply and demand and hence is considered a fair method of determining profits/earnings and losses that are distributed to the transactors. This fairness in compensation, which is directly tied to the real economy, is determined by the real economy; such elements are compromised when one considers certain redemption and return determination practices.

International Journal of Management and Applied Research, 2019, Vol. 6, No. 4 
(e) The over-emphasis of PLS and the absolute prohibition of commercial debt overlook objectives. Since even some empirical research has established that several factors contribute to the tendency towards debt-based business finance than that of PLS (Jalaluddin, 2011). Thus, it is an approach that reduces Shariah transactions to some principles over others and is bound to hinder the realization of other objectives. For example, while PLS is only a means of achieving fairness in distribution, riskaverse investors will be forced to put their money elsewhere or not invest them at all thus hindering production, asset development, public benefit and circulation (exchange) of wealth, which are some of the objectives in themselves as well as means to achieving other objectives. They contribute to the ultimate objective of preserving wealth through growth and development. While such a qualitative hypothesis needs to be tested, they are advanced as arguments against those who restrict financial dealings to a narrow scope of PLS-based transactions.

Figure 1: Maqasid matrix

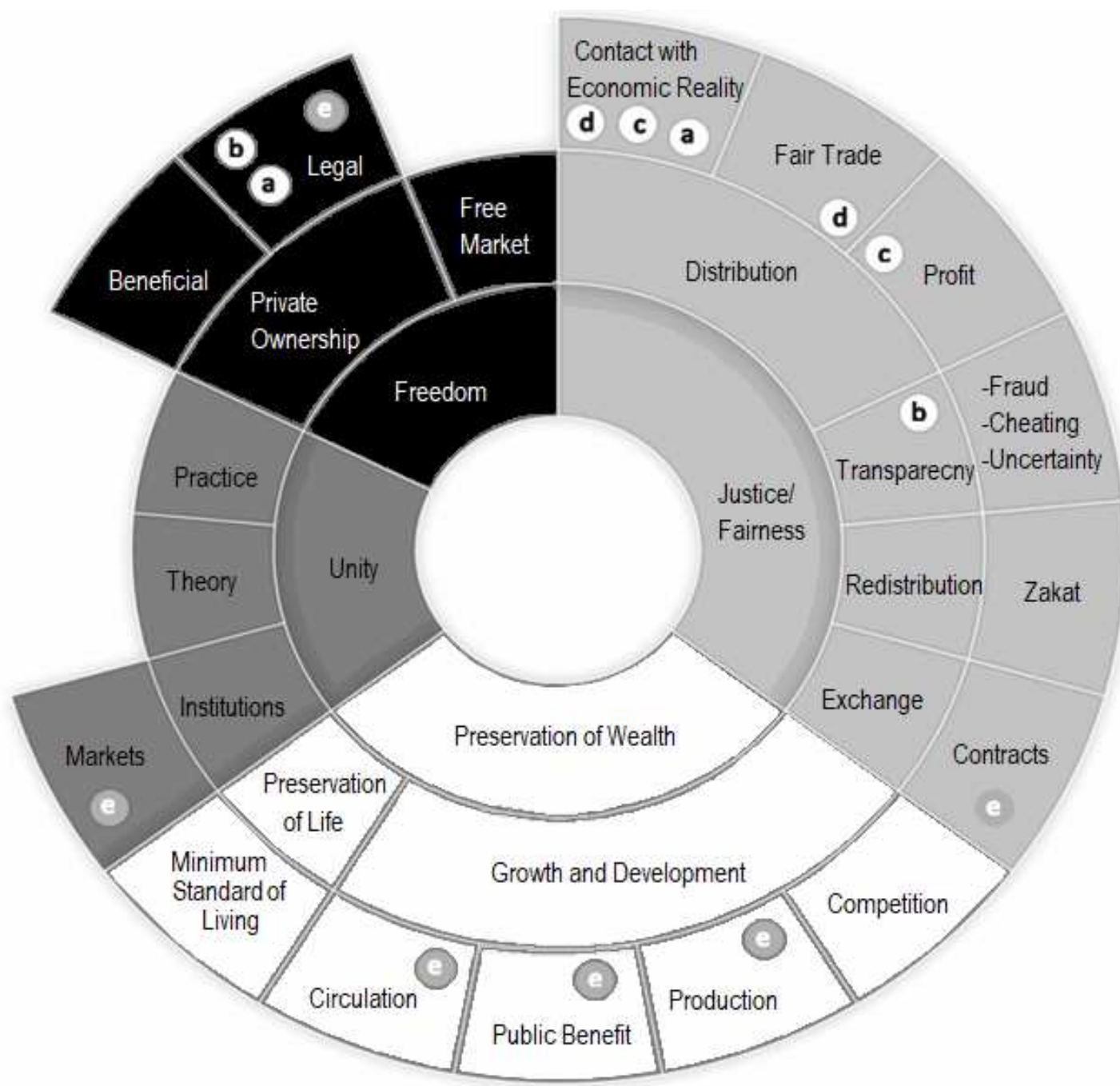

Source: Author's interpretation

The conclusion to draw from this diagram is that at the detriment of achieving partial objectives such as proper legal ownership, real sector correlation, fair profit/loss 
sharing, and asset-based instead of debt-based arrangements, other objectives which pertain to the preservation of wealth and increased unity/cooperation through economic activity are compromised including the lack of circulation of wealth due to lacking markets, the hampering of production and their resulting public benefit.

\section{Conclusion and Recommendations}

The current sukuk structure, issuance and redemption practice of the literalist approach has a lot of questionable elements that contravene the principles of Shariah and muamalat law including maqasid, ma'alat, legal ownership, real economic/sector contact and the asset-based nature of contracts underlying sukuk structures. The murabahah, salam and istisna' contracts all entail a claim on debts or assets receivable which renders them debt-based contracts with what comes with that of trading restrictions. While the legal ownership is transferred to the sukuk holders, it is mainly beneficial, with strict limitations on the ability of sukuk holders to dispose of their share in the underlying assets as they wish.

The PLS elements of both asset-based and asset-backed sukuk's underlying contracts are done away with the PU's and the definition of returns through certain controversial methods. All such issues contribute to the loss of contact with the real economy in which asset owners cannot dispose of their share in the assets as they wish, nor is the return on these assets valued according to market prices. On the other hand, overidealizing the necessity for such elements first of all hinders a lot of other Shariah objectives from being realized, and second, is not in line with their respective positions in the maqasid (objectives) matrix of Shariah law.

The issues were classified in the maqasid (objectives) matrix to test if their idealization is warranted to the extent that it actually is, and also to appraise industry practice which chooses literalist applications of contract law in securitization rather than a spirit-oriented approach. The conclusion was that industry practice, although realizing objectives of wealth preservation and unity/cooperation, compromised other objectives that pertain to just/fair distribution and private ownership.

Hence, it is recommended that a gradual transition to realizing all of the objectives highlighted if possible, and if not that an attempted transition to pure asset/equitybased sukuk setups, not be radical and trigger a frenzied flight to interest-based bonds for financing purposes since the demand for equity arrangements is quite limited and segmented as in Khan (1995). The feasibility of non-equity sukuk and acceptance is much greater for a slew of reasons and any sort of radical change may bring about unwarranted consequences such as losing the currently developed customer base.

Alternatively, PLS-based financing may be adopted on a wider scale - since it is more morally ideal than debt - while maintaining limited risk levels by diversifying which reduces the risk of individual assets/projects. Moreover, a gradual move towards PLS arrangements bypasses the collateral requirement which may even give sukuk higher rating as in conventional banking in which a firm gets financing by virtue of its collateral. This may direct investors' attention away from rating towards efficiency of the issuer or underlying asset as is also discussed in (Chapra, 1985).

International Journal of Management and Applied Research, 2019, Vol. 6, No. 4 


\section{References}

1. Accounting and Auditing Organization for Islamic Financial Institutions (AAOFI) (2018), Shariah standards, Bahrain: AAOIFI.

2. Al-Amine, M. A. B. M. (2008), "Sukuk market: innovations and challenges", Islamic Economic Studies, Vol. 15, No. 2, pp. 1-22.

3. Ali, S. S. (2005), Islamic capital market products: Developments and challenges, Jeddah: Islamic Research and Training Institute.

4. Al-Raysuni, A. (2013), Maqasid al-maqasid: al-ghayat al-ilmiyyah wal'amaliyyah li maqasid al-Shariah, Beirut: Arab Network for Research and Publishing.

5. Chapra, M. U. (1985), Towards a just monetary system, Leicester: The Islamic Foundation.

6. Choudhury, M. (2015), "Res extensa et res cogitans de maqasid as-Shariah", International Journal of Law and Management, Vol. 57 No. 6, pp. 662-693. https://doi.org/10.1108/IJLMA-07-2014-0046

7. Dusuki, A. W. (Ed.) (2016), Islamic financial system: Principles \& operations, $2^{\text {nd }}$ ed., Kuala Lumpur: International Shariah Research Academy (ISRA).

8. Dusuki, A. W. and Mokhtar, S. (2010), Critical appraisal of Shariah issues on ownership in asset-based sukuk as implemented in the Islamic debt market, International Shariah Research Academy for Islamic Finance (ISRA).

9. El-Gamal, M. A. (2006), Islamic finance: Law, economics, and practice, Cambridge: Cambridge University Press.

10. El-Mesawi, M. E. and Ahmed, B. A. M. (2016), The Shariah goals pertaining to economic wealth and their means in Imam Mohammad al-Tahir Ibn Ashur's work, at-Tajdid, Vol. 20, No. 39A, pp. 235-265.

11. Ghani, N. A. R. (2018), "Beneficial ownership in sukuk ijarah: A Shariah appraisal", International Journal of Islamic and Middle Eastern Finance and Management, Vol. 11, No. 1, pp. 2-17. https://doi.org/10.1108/IMEFM-02-20170026

12. Hanif, M. (2016), "Economic substance or legal form: an evaluation of Islamic finance practice", International Journal of Islamic and Middle Eastern Finance and Management, Vol. 9 No. 2, pp. 277-295. https://doi.org/10.1108/IMEFM-072014-0078

13. Hassan, K. and Lewis, M. (Eds.) (2009), Handbook of Islamic banking, Cheltenham: Edward Elgar Publishing.

14. Jalaluddin, A. (2011), Profit/loss sharing method of finance: An empirical study in a Western country, Gombak: A.S. Noordeen.

15. Kahf, M. and Khan, T. (1992), Principles of Islamic financing, Jeddah: Islamic Development Bank.

16. Kamali, H. (2007), "A Shariah analysis of issues in Islamic leasing", Journal of King Abdulaziz University: Islamic Economics., Vol. 20, No. 1, pp. 3-22.

International Journal of Management and Applied Research, 2019, Vol. 6, No. 4 
17. Khan, T. (1995), "Demand for and supply of mark-up and pls funds in Islamic banking: some alternative explanations", Islamic Economic Studies, Vol. 3, No.1, pp. 1-46.

18. Krichene, N. (2013), Islamic capital markets: Theory and practice, Singapore: John Wiley \& Sons.

19. Lahsasna, A. and Idris, U. (2008), "Examination of the AAOIFI pronouncement on sukuk issuance and its implication on the future sukuk structure in the Islamic capital market", in: 6th International Islamic Finance Conference, Kuala Lumpur.

20. Laldin, A. M. and Furqani, H. (2013), "Developing Islamic finance in the framework of maqasid al-Shariah", International Journal of Islamic and Middle Eastern Finance and Management, Vol. 6 No. 4, pp. 278-289. https://doi.org/10.1108/IMEFM-05-2013-0057

21. Magalhães, R. and Al-Saad, S. (2013), "Corporate governance in Islamic financial institutions: the issues surrounding unrestricted investment account holders", Corporate Governance, Vol. 13 No. 1, pp. 39-57. https://doi.org/10.1108/14720701311302404

22. Rizvi, S. A., Bacha, O. I. and Mirakhor, A. (2016), Public finance and Islamic capital markets, New York: Palgrave Macmillan.

23. Safari, M., Ariff, M. and Mohamad, S. (2014), Sukuk securities: New ways of debt contracting, Singapore: John Wiley \& Sons.

24. Tariq, A.A. and Dar, H. (2007), "Risks of Sukuk structures: Implications for resource mobilization", Thunderbird International Business Review, Vol. 49, No. 2, pp. 203-223. https://doi.org/10.1002/tie.20140

25. Wilson, R. (2004), "Overview of the sukuk market" in: Adam, N. J. and Thomas, A. S., Islamic bonds: your guide to issuing, structuring and investing in sukuk, London: Euromoney Books. pp. 6-7.

26. Wilson, R. (2008), "Innovation in the structuring of Islamic sukuk securities", Humanomics, Vol. 24, No. 3, pp. 170-181. https://doi.org/10.1108/08288660810899340

International Journal of Management and Applied Research, 2019, Vol. 6, No. 4 